\title{
John Dewey, Phenomenology, and the Reconstruction of Democracy
}

\author{
Lars Løvlie*, \\ Institute of Education, University of Oslo, Oslo, Norway
}

\begin{abstract}
In this article, I propose a link, or at least a family likeness, between two great traditions, Dewey's pragmatism and continental phenomenology and hermeneutics, held together by an overlapping epistemological and ethical outlook. My argument is based on a tripod of terms: situation, experience, and reconstruction. I start by describing 'situation' as the a priori condition for having experiences: there simply has to be a situation for sensing, thinking, and making decisions to take place. My next point is that experiences are necessarily place bound, local, and everyday phenomena. Experiences are relational in the sense of a subject who relates to the (material) world and to significant others - the subject not as an isolated ego, but as being-withthe-other. The link between experience and reconstruction may not be so obvious to us. But it is Dewey more than anybody else who has made a case for democracy as a political reconstruction of our everyday experiences. There is a connection between his epistemological and ethical outlook, and political action as part of an education for a democratic life.
\end{abstract}

Keywords: pragmatism; phenomenology; situation; experience; democracy

Received: May 2015; Accepted: September 2015; Published: November 2015

\section{The argument}

In 2007, my essay 'The Pedagogy of Place' was published in Nordisk Pedagogik. One of my arguments was that pedagogy in the wide sense is basically earthbound, territorial, and local - as an intentional activity, it literally takes place somewhere in the home, in our kindergartens, in our schools and universities, in our workplace, and in our leisure activities. All experience, I assumed, is bound to situations, and all teaching requires a setting - the places where experiences are made and enacted. In short, place is the condition of possibility of pedagogy. This condition is, then, both the topos - an apt term in this context - and topic from where we should reclaim for pedagogy the territory of discourse that has, over the past decades, been seized by the abstract vocabulary of contemporary managerial thinking. The politics of that vocabulary has introduced a new formalism in our schools, less based on the authority of the teacher, and more on impersonal rules and steering mechanisms. This formalism in education

^Correspondence to: Lars Løvlie, Institute of Education, University of Oslo, Boks 1072 Blindern, NO-0316 Oslo, Norway. Email: lars.lovlie@iped.uio.no 


\section{Løvlie}

canonises skills and their measurement in closed schemes that, for all practical purposes, tend to sap experiences of their vital energy. The 'existential matrix' of experience-Dewey's words - is lost in the arid landscape of prescribed content and procedures. The new formalism is abstract in the literal sense of a thinking that has severed its precious links to the lived world of teachers and students. It is also paradoxical: the better formalism succeeds in its quality control, the more it seems to forget its experiential basis, and the further it is removed from the personal and common democratic virtues it purports to foster. This, the broken relation between the individual and society, is a theme broached in Dewey's Individualism Old and New, written on the eve of the Great Depression in 1929 and foreshadowing the current reign of elitist governmentality and neo-conservative populism (see Dewey, 1929, p. 168). How does this tally with Dewey's phenomenology, if there is such a thing? I shall develop my answer in three steps, under the main headings of situation, experience, and reconstruction.

Dewey's phenomenology can be traced, I believe, in most of his books. Victor Kestenbaum, for one, seems to agree (Kestenbaum, 1977, 2002). My point of departure is Dewey's logical writings because they give a brief and concise presentation of his basic ideas of situation and experience, and how both impinge on his overall educational theory. In Essays in Experimental Logic (1916b), he states that 'it is the needs of a situation that are determinative' and that 'it is only by reflection upon the place of the agent in the encompassing situation that the nature of his needs can be determined' (Dewey, 1916b, p. 70). In other words, he puts situation before the individual in the logical order: the situation emplaces the person and so it is the place or locus that determines the onset and course of individual experiences. This view, worked out around 1900, is repeated in his Logic: The Theory of Inquiry (1939) where he introduces the idea of 'a universe of experience' as embedded in situation (Dewey, 1939, p. 68). Situation in the singular, then, points to the quasitranscendental presupposition in Dewey's theory of experience (although Dewey would not speak in those terms). As for the reconstruction of democracy, in Liberalism and Social Action (published 1935), Dewey gives an historical account of the crisis and renascence of liberal democracy, latched on to his earlier book The Public and Its Problems (1927). The juxtaposition of the 'phenomenology of situation and experience' (my terms) and the reconstruction of liberalism in terms of a 'method of democracy' (Dewey's term) may help us recreate the idea and practices of democracy as processes of conjoint action in our schools and universities, in non-government organisations, and volunteer associations. This chimes with Dewey's view that democracy is an ongoing task, and that this task cannot be fulfilled by fiat and management, but is realised in transaction and participation in current affairs. There is an overlap in that view between education and democratic action, between school and political work, or to put it like this: Dewey thinks that public institutions are - or should be - both political and educative. Let us first have a closer look at 'situation' as used by Dewey in relation to phenomenology as the study, literally, of that which appears in experience. 


\section{Situation}

Situation is co-existent with and concurrent in all experiences, that is to say, there is no experience without a situation (and no situation without an experience). To be without a situation is to be without a world in which experiences can be had or made, it would be the weird existence of the famous brain in the vat, alive and without action, only given to the stimuli from its handler. In the Logic of 1939 Dewey writes: 'For we never experience nor form judgments about objects and events in isolation, but only in connection with a contextual whole' (Dewey, 1939, p. 66). And he goes on to argue that mind and world come together, or rather exist in experiences made within 'total qualitative situations'. Experiences are had or felt before they become objects of observation and are controlled by concepts and schemata. The situation in the general sense of a contextual whole is marked by a single, pervasive, and felt quality - these are terms that Dewey uses to describe the feelings of situations as threatening or secure, cheerful or distressing. Significantly he describes such feelings as they occur in existential situations as 'unique and inexpressible in words' (Dewey, 1939, p. 70). The immediate feel of a situation is ineffable but can subsequently be rendered in prose and poetry, such as in Martin Heidegger's descriptions of beingin-the-world in terms of Stimmung or mood, of being attuned to the world before we relate consciously to the particular things in that world; in Hans-Georg Gadamer's use of 'horizon' for the undefined background that foregrounds processes and procedures of definition, as prescribed in a curriculum; or in terms of Michael Polanyi's tacit dimension (Gadamer, 1965; Heidegger, 1996; Polanyi, 1966). Common to these points of view is that they do not start from the division between mind and world, feeling and thinking, but from their co-existence in particular historical settings.

In Philosophy and Civilization, a collection of essays published in 1931, Dewey is again quite explicit about this. There he reiterates what was evident to him already around 1900, that the basic stuff or subject matter of cognition 'is dominated and characterized by a single quality without which the logical force of objects and their relations [are] inexplicable'. In other words, logic cannot be detached from its emotional or aesthetic content. He adds two salient glosses that mesh with what is already said. First, he writes that 'The situation as such is not and cannot be stated or made explicit. It is taken for granted, "understood," or implicit in all propositional symbolization'. Then he goes on to say that the situation controls thought by enabling us take hold of where we are and what we are thinking of, like what we do when we lose our bearings and try to regain what we wanted to express in speech or writing in the first place. We are aware of the pervasive quality of the 'mood' not by itself 'but as the background, the thread, and the directive clue in what we expressly think of' (Dewey, 1963a, p. 99). Surely this is not to be taken as a psychological fact in a causal chain, or what we get when the reporter asks the survivor what she felt during the twister that devastated her home. This is more like the general feeling of apprehension and anticipation a child has on his or her first day in school, as they give her 


\section{Løvlie}

experiences their particular hue. It is an event given to phenomenological analysis rather than to psychological explanation.

To sum up, Dewey describes the situation as a 'unique and inexpressible' whole, simply had as an immediate experiential quality or mood. Or, if you will, a 'horizon' that cannot in itself be an object of observation, because the horizon is what makes things stand forth in the first place. There is also the further observation that Dewey, in Experience and Nature, mentions the Husserlian-like idea of intentionality, by saying that 'In truth, attitudes, dispositions and their kin ... are always of, from, toward situations and things' (Dewey, 1958, p. 238). If we add another observation from the same book, that 'philosophy is a critique of prejudices' (Dewey, 1958, p. 37), which again concurs with Gadamer's hermeneutics, we get an idea of what might be worked out under the heading of 'Dewey's phenomenology', and how it can affect our interpretation of Dewey's idea of education. But even if these points add up to a description of Lebenswelt (Husserl), they do not make him into a continental phenomenologist. Dewey's inspiration in this matter came, as far as I can see, primarily from William James and his French colleague and friend Henri-Louis Bergson, with G.W.F. Hegel's theory of action lingering in the background. If Dewey ever read Heidegger (as far as I know, Dewey did not read either him or Gadamer), he would certainly cringe at the latter's deep and explicit anti-democratic thinking and abject anti-Semitism. As for Gadamer, I see him as a philosopher of culture rather that of politics in the sense developed by Dewey. Dewey's logic of inquiry is embedded in the enlightened - and Darwinian - idea of a free, experimental, and progressive method for the biological and cultural reconstruction of a democratic society.

\section{A sense of place}

What is the impact of this on Dewey's idea of education and democracy? His phenomenology states that experience (mind you: not learning) takes place when persons embedded in their local culture and its traditions, find themselves in situations, immediate and non-descript, characterised by a vague but often strong intuition or sense of what the situation portends, expressed in feelings of avoidance or attraction (which cannot, of course, be reduced to Jeremy Bentham's pain or pleasure). This feeling is existential, rather than individual, and it relates to being given to a world not of one's own making, a world grown from the past and laden with fear and hope, with its impact as weird or scary, safe or secure - this is Dewey's take on the human condition at large. Place is pre-instrumental and centred around an initial orientation as to where I am and to what this situation means in terms of Stimmung or mood (Stimmung being a key term in Heidegger, referring to Stimme or voice, and to hearing rather than to seeing). An education that does not start in the common world of adults and children that are tuned in to each other, forgoes this initial orientation. It makes us ignore the common background - the historical heritage - at the very place from where it might be recollected and replenished. This forgetting or disregard not only means that the child is not seen and met on his or her individual 
home turf - this is not even Dewey's main point here - but that the prime access to a common history is barred, so that the existential premise of education does not come fully into view. Without engaging common values, the basic educational attachments between adults and children are either lost or misrepresented, as is characteristic of what I have called the tool-box view of education (Løvlie, 2013a).

One might ask how social critique is possible when education loses its bearings in communal life, when individual voices are stifled, and conflict and critique between generations cannot be adequately expressed because school authorities and educationalists are oblivious of the loss of historicity and of historical knowledge. When situations are furnished only by facts, either from bare scientific or common sense sources, we may fall victims to bad judgment and contradictory behaviour because our interpretations fail the situation and leave its meanings unaddressed. In Dewey's terms, when situations are fixed in 'predetermined conceptual and theoretical scheme[s]', then 'sensitivity to the quality of a situation as a whole' is defeated. Such strategies ignore that 'a problem must be felt before it can be stated' (Dewey, 1939, p. 70). Dewey's version of what might arguably be called the American phenomenological tradition-William James again comes to mind-lies at the root of his conception of education for democracy and is vital for a full interpretation of his logic of experience and inquiry and, as a corollary, his 'instrumentalism' (see Løvlie, 2013b).

A sense of place makes situation, horizon, and context the basis of educational thinking, a thinking that reflects the phenomenological approach in its initial understanding of what education is all about. The proximate practical outcome of this reflection are varieties of problem-oriented education or situated learning, ideally based on local curricula, such as in the Nordic heimstadlare at the beginning of the past century. Let me qualify what I suggested in my 2007 essay by taking Dewey's phenomenology as giving answers to questions such as: What is the mood or feel of the situation for this particular group of children in the classroom? Or: How do they express their feelings in mimicry, movement, or words? To be mindful about such questions nudges us to appreciate the situations that mark our existence with others in a common world. These are all 'objective' questions for a caring teacher and subject matter for her analyses and reflections.

Now let me sum up. Situation in the singular is a logical concept, a blanket term for the fact that before anything else, we are place-bound creatures in a world that is given to experience, interpretation, and action - given in the sense of a gift rather than an individual achievement. This existential matrix (my term) typically matches activities that bring the salient features of situations in the plural to the fore, that is to say, situation is the background for all the particular situations that we deal with in everyday life. So there is situation without an s, which is abstract in the sense of being a condition of human experience, what surrounds or frames our lifeworld. Then there are situations with an s, those we encounter head on when they turn up as problematic in our daily life. Situation and situations do not belong to different slots or boxes in the world, they interact in experience and action, and may thus be called dialectical (although Dewey would not be happy with the word). 


\section{Løvlie}

I suggest that Dewey's phenomenology be the name of the double perspective of situation with and without an s, and with our attempt to cope with it and come to terms with it.

\section{The situation and the subject}

We tend too easily to slip into the habit of thinking of the mind and the world as things apart. This Cartesian world view is contradicted by a sense of place that starts within the life that we already always live. Neither experiences nor meanings are just things in the mind, flittering about as so many representations of reality. Experience should be analysed in its inflection with the material world, not only as individual skills because personal competence is embedded in traditions that you and I are part of. There is, of course, the wrongheaded view that a felt, qualitative experience can only be a private and subjective matter - the fiction of privative individualism, privative in the sense of depriving the individual of his or her social life. The view touches a truth, however, since there are no experiences without sentient beings to make them. On the contrary, you will be hard put to describe competences isolated from the complex interface between persons, and between persons and things. The attempt to define competences in terms of individual achievement is doomed to failure because it disregards this basic fact.

Reflecting on situations as given to interpretation and action suggests that the stuff of interpretation is already emplaced in the existential matrix or interpretive horizon (Gadamer) within which you and I already live. Who, then, is the subject of a situation? My answer in the 2007 essay was: 'The situation itself!' And I went on to say that 'Just as the subject of an interpretation is the interpretive situation, the subject of an experience is the experience made or undergone' (Løvlie, 2007, p. 34f). This utterance may seem a bit rash, but it is not taken out of thin air. Hegel laid the ground for this view in the introduction to the Phenomenology of Spirit by proposing that the subject is the unity or relation of subject and object (Hegel, 1977, p. 54f). I take this to be the insight that inspired Dewey to describe human life as cooperative, and democracy as its foremost expression. Gadamer (1965) made a similar point in Truth and Method when he said that 'The subject of the play ... is not those who play but the play itself' (p. 102), proposing that regardless of our egocentric fancies, we are children of history and tradition. Dewey (1958) for his part wrote that 'In the first instance, it is neither exact nor relevant to say "I experience" or "I think." "It" experiences or is experienced, "it thinks or is thought, is a juster phrase" (p. 232). I would agree that to replace ' $\mathrm{I}$ ' with 'It' is an awkward way of referring to a common world of relations, but it does the job of freeing epistemology of the ego as the pivot of experience.

Let me avoid a possible misunderstanding. The quote does not say that subjects or persons do not exist within the situation as individuals, each with a unique bodily and mental presence, and with particular feelings, needs, and intentions. It is rather apt to say that the subject does not enter into the equation as Charles Taylor's 'unencumbered self', or a self 'poor in world', as Heidegger has it, and isolated in the 
'privatism' of ego-related actions (Taylor, 1989). Dewey's individuals exist within a world of participation in a quest for the common best interpretation of the world and the concomitant best way of solving shared problems within shifting social limits, described in terms of a liberal democracy geared to 'equality of opportunity' (Dewey's term) and the welfare of its citizens. When Dewey (1916b), in Essays, proposes that 'it is the social situation as a whole ... that calls forth and directs thinking' (p. 122), he reiterates that experience is 'of' the situation rather than 'in' the consciousness of the individual - the container view of the 'I'. He takes issue with terms such as 'subject' or 'knower', as long as they refer to an ego or a self as the beholder of the world - the spectator view of the world. He prefers to see thinking in terms of real persons in their actual transaction with persons and things. He rejects the categorical split between mind and world and reconstructs the relation as one of 'intelligence', that is to say, thinking cum action as a way of problem-solving in the wide sense of securing biological and cultural reproduction. Let me use autobiographical writing as an example, because there you stress the biography as well as the auto or self. In biography, the self comes to life within its historical lifespan; it is embedded in a particular life and is substantially expressed through that life. If the stress lies on autós (the Greek equivalent of self), you are easily hijacked by the idea that the self is something unto itself, that it resides somewhere within your skull and springs into action and creates the problematic situation de novo - the dream of a constructivist gone astray. Critical of John Stuart Mill, Dewey (1927) argues that the actions 'of individual men are in the concrete what they are, their beliefs and purposes included, because of the social medium in which they live' (p. 195). Dependent on man's 'biological make up', individuality grows out of the individual-world relations within the person's ambience.

\section{Experience}

I have treated situation and experience as coexisting in the sense that there is clearly no experience without a situation, and just as clearly there is no situation without someone to experience it as such. I have described situations in terms of places, that is to say, of people mentally, geographically, and historically emplaced in their local habitat. It implies bodily orientation that expands from a situation taken directly in a gross or total grasp - the bodily feel of presence in the world. It implies the use of symbols and interpretation in the effort to better grasp the features of a situation with questions such as: What is the meaning of what happened? Or: What are the particulars of this situation? Or: Where do we go from here? The distinction between gross and particular experience may illuminate the interplay between the non-cognitive contextual whole of life experiences, and how I as a person can come to terms with the problems that arise within it. Dewey's basic non-cognitive approach to experience should give pause to strong cognitivists and constructivists in pedagogical thinking. I do not think that we can tag Dewey as a constructivist, if only because of a phenomenology that issues in a reconstruction of the world within which we live as historical beings. My view is also supported by his distinction 


\section{Løvlie}

between 'doing' and 'undergoing'. Situations, in the primary existential sense of life determined by nature and emplaced in culture, entail an 'undergoing' that governs my 'doing' or coping with them. The distinction between having an experience and making an experience points to the dialectics of a common tradition on the one hand; and the 'reflective thinking [that] transforms confusion, ambiguity and discrepancy into illumination, definiteness and consistency', on the other (Dewey, 1958, p. 67). Reflective thinking issues in the 'empirical method' or what Dewey in other contexts describes as the method of inquiry (see Løvlie, 2013b). The scope that Dewey gives to 'science' and the method of inquiry seems to me to mark the exact crossroads where Dewey the pragmatist takes a course different from the continental phenomenological and hermeneutic tradition. I must confess to still being befuddled by Dewey's belief that a common ground for social and pedagogical action could be established by way of a simple 'technique': the method of inquiry. But it would take me too far afield to expound on this here.

Dewey typically drifts towards Hegelian communitarianism rather than Kantian autonomy when he makes an important distinction between consciousness and 'mind'. In Democracy and Education, he says that

... mind is not a name for something complete in itself; it is a name for a course of action in so far as that is intelligently directed; in so far, that is to say, as aims, ends enter into it, with selection of means to further the attainment of aims. Intelligence is not a peculiar possession which a person owns; but a person is intelligent in so far as the activities in which he plays a part have the qualities mentioned (Dewey, 1916a, p. 132).

Mind is social through and through. I would like to stress two points, equally relevant for education and for politics. First, Dewey's phenomenology points out that we already always sense or locate or find ourselves in a common world, in which young and old take part. Here the expression 'presence of mind' takes on its particular meaning. It refers to a presence in a world, to being-there-with others. In educational terms, it would mean being attentive to the atmosphere in the classroom, to its mood or Stimmung, to the here and now as caught in a glimpse or in the course of prolonged interaction. It is to be attuned to the situation felt as a manifold whole; it is the immediate feel that tells the teacher how to begin the day with his or her students. Second, experience issues from social actions or, in Dewey's vocabulary, in the 'reflections' and 'transactions' that issues in joint problem-solving. In educational terms, this means close attention to the work that is going on, to its beginnings and endings, and to what takes place in the space between them. This is what grounds his 'instrumentalism': the cooperative task of transforming vague, indistinct, even confused situations into ones of possible action. That allows for procedures guided by general aims-in-view and leads to learning processes that pleases or frustrates but ideally, particularly within the arts, end in a harmonious whole. I must confess to a certain doubt about this ideal of harmony in Dewey, partly inspired, I think, by the idea of homeostasis, a biological conception popular at that time, but at odds with his grasp of the stream of experience as proposed by William James. 
Process is all important, and so is the hypothetical and experimental attitude. Basically that does not allow for readymades in the classroom, for example, pre-made programmes and schemes that cut teachers and students off from making unusual and surprising experiences. Process is contained in Dewey's method of inquiry, which moves from a felt problem to its termination in a possible solution. The stress lies not on the outcome but on the course of action plus the outcome. Dewey's term 'endin-view' denotes aim, purpose, and objective rather than the 'finalities' (also his term) reached and recorded as test scores. Aims are tried out in the course of experiences open to the exigencies and surprises of the world. As he has it in Democracy and Education, an aim means foresight and gives direction to an activity; it leaves the activity free to its 'intrinsic continuity' rather than steering it along a predetermined course from A to B (Dewey, 1916a, p. 102). An end-in-view, he reiterates in Experience and Nature, is 'a prediction usable as a plan in shaping the course of events' (Dewey, 1958, p. 101). This view is very different from the fast food thinking that has produced a system of tools that bars teachers and students from being creative and innovative and also tends to de-professionalise teachers by robbing them of their professional dignity and discretion. The deeper problem is a corrosive paternalism that defeats the idea that education for citizenship should encourage everyone's right to expression in play or work and also support their capability to take an independent stand on moral and political issues. To sum up this section: experience is in and of situations rather than of and by the ego. Intelligence is distributed, that is to say, it is a quality of cooperation rather than a property of individuals; education is come by in processes of open-ended inquiry rather than from defined procedures and fixed outcomes. Learning is the slow and painstaking process that builds the house of education from the ground up; it includes close attention to the impulse, framework, and course of experiences.

\section{Reconstruction of democracy}

So far I have proposed first that Dewey's type of phenomenology, which aligns him with proponents of the continental tradition, sets out from a sense of place that includes being, knowing, and acting in the world. Second, what realises this mode of living is what Dewey, in the Public and elsewhere, likes to call 'conjoint' activities. Now these aspects, sense of place, presence of mind, and social action, undergird both education and political judgment. His political theory is consistently grassroots, poised against elitist domination and directed at the American middle class as advocates of 'education with a political purpose', as Ryan (1995, p. 296) has it. On one of the first pages of the Public, Dewey asks Americans not to be led astray by the notion of the state, because it easily leads to discussion of political ideas and concepts rather than taking hold of the 'facts of human activity'. It is better, he says, to start from everyday common life and see if that might lead us to 'the marks and signs which characterise political behavior' (Dewey, 1927, p. 9). When the idea of a middle class public is given pride of place, then 'There is no sense in asking how individuals come to be associated. They exist and operate in association' (p. 23) within the limits 


\section{Løvlie}

given by parents and teachers, civil servants, and politicians. Between the wars, Dewey was thinking of politics beyond the two American parties, the Republicans and the Democrats, and in 1929 he placed hope in third-party politics in The League for Independent Political Action.

The people in the sense of the populace may be a riotous mob as well as a community of reasonable problem solvers. Dewey prefers to speak of the public rather than of the people, avoiding the pitfalls of referring to a Volk with its nationalistic and racist connotations. In order to be legitimate, the public must be organised within a state that governs by law and takes care of shared interests. The state is dependent on civil servants who employ the law with an eye on the public good. The state has monopoly of power over its subjects, but the public is defined by its mutual caring for association and interaction, for organised avenues of disagreement and cooperation, and for informal and formal educative experiences. 'Thus man it not merely de facto associated, but he becomes a social animal in the make-up of his ideas, sentiments and deliberate behavior' (p. 25). Dewey declares that the state ought to be 'rediscovered' and more generally that the 'formation of states must be an experimental process' (p. 33). Who 'rediscovers' the state? The answer is the public, that is to say, those who define themselves as participants in the reconstruction of democracy, a form of government and life that is never finalised but comes into being or brings itself about.

The public is created by associated activity all the way down to 'villages and neighbourhoods', whereas the state, bound by the Constitution and represented by its politicians and civil servants, gives that activity its legal authority. Dewey, then, has a definite penchant for a bottom-up politics rather than one dominated by the established elites. In the Public he says that 'one of the first ideas ... in the growth of political democracy' is the 'judgment which is formed and entertained by those who constitute the public'. That is to say, the formation of public opinion is, in the best of worlds, the realisation of its qualities in 'communication' (p. 177). This is as close as you can come to democratic political institutions: the ballot and the uses of argument and negotiation, all informed by 'social inquiry'. Dewey's vision of the relation between the state and the public is that between legal authority and public opinion in tandem.

The lasting, extensive and serious consequences of associated activity bring into existence a public. In itself it is unorganized and formless. By means of officials and their special powers it becomes a state. A public articulated and operating through representative officers is the state; there is no state without a government, but also there is none without the public (Dewey, 1929, p. 67).

No wonder, then, that Dewey stresses the vital importance of a public education. In Liberalism he says that 'The first object of renascent liberalism is education', which is 'to aid in producing the habits of mind and character, the intellectual and moral patterns, that are somewhere near even with the actual movements of events' (Dewey, 1963b, p. 61). I take this to mean that teachers and students in our schools 
and universities should partake in current political affairs, learn from them and press for changes. Dewey's liberalism, as should be clear from now, is not what in the Nordic countries currently goes under the name of Neo-Liberalism. In Liberalism, he launches a scathing attack on a liberalism (read neoliberalism) that makes charity into 'parasitical dependence' and makes the competitive system a 'scarcely disguised battle' for individual privileges. Dewey rather comes forth as a social democrat, now a term of abuse among American conservatives. He does not much believe in 'the method of discussion', for this, he thinks, belongs to the privilege and power of the academic elite and does not 'bring out necessary public truths' and 'has nothing in common with organized coöperative inquiry' initiated by public-minded people (Dewey, 1963b, p. 71). So much for Jürgen Habermas' belief in argumentation as the pivot of political rationality, it seems!

\section{The future of the public}

What to make of Dewey's Public today? The Public was published in 1927, Individualism was written on the eve of the Wall Street crack in 1929, and Liberalism followed during Franklin D. Roosevelt's first New Deal - the book came out 2 years into Roosevelt's incumbency, in 1935. He also wrote within the new industrial nation state. We now live in a time of renascent predatory capitalism, as witnessed in the 2007 financial meltdown in the United States and its aftermath, the European debt trap. History repeats itself, it seems. We also live in the time of the Internet and the Edward Snowden leaks, which show that the American National Security Agency has extended its 'signal intelligence information' to cover all American citizens' Internet use, and has been hacking businesses such as Google and Yahoo, and has been eavesdropping on Angela Merkel's mobile phone, only to mention the most publicised events of 2013. Then add the torture programme practiced by the Central Intelligence Agency at Guantánamo under George W. Bush's administration, as recently documented in the US Senate Intelligence Committee Report on Torture, published in December 2014; and President Barack Obama's ongoing and unlawful drone war in Pakistan and Yemen. Top it all with the political antics of the populist Republican Tea Party movement, and you come to think that Dewey's programme for democratic political action from below is but a pipedream.

Was Dewey realistic about the prospects of American democracy? Dewey seemed to be in two minds about it: critical pessimist and hopeful optimist. He spends a chapter in the Public on 'the eclipse of the public' before he strikes a more confident key in the next chapter on 'the Great Community'. In Individualism, he condemns the old American 'rugged individualism' before he again raises the hope for a new, regenerative individualism. In the long run, the anticipated reconstruction of society from below has come to grief in the era of Neo-Liberalism of Reagan and Thatcher. The American financial meltdown of 2007 and its aftermath has bolstered economic and bureaucratic governmentality and reduced 


\section{Løvlie}

the standard of living of millions of American and European citizens. It may seem that social democracy — 'socialism' in the United States, a derogatory term - in its effort to create equity, political power, and welfare for all has been only an interval in Western history after the Second World War, at best an anomaly in the history of capitalism, as witnessed, for example, by Robert Putnam (2015), in his recent book Our Kids: The American Dream in Crisis. Yet, there is a faint and lingering hope around 2015 in the new political parties in Europe, the Syriza in Greece, and Podemos in Spain, which can be termed middle class movements based on the solidarity of the have-nots against the power of the European political and moneyed elite. These movements, based on the vitality of a civil society, have a political and social force that may tilt the balance somewhat towards political actions and institutions that may realise some of Dewey's ideals of a participatory democracy. As for education, the current Nordic scene is dominated by the political-bureaucratic complex and its attempt to turn education into a matter of disciplining a future workforce. In the process, the authorities see public doubt and dissent as a threat to be avoided and derailed. The recent critique from educationalists, teachers, and parents against political paternalism may drive wedges into the systems of control that are now in place. When tacit opposition turns into political action, Dewey's idea of the public is revitalised. Its vision is that education should be based on political will, scientific fact, and social control; tempered by the aims and arguments of a public of parents, teachers, and students; and bolstered by the wisdom garnered from lived experience.

\section{Biography}

Lars Løvlie is Professor Emeritus of Philosophy of Education at the Institute of Education, University of Oslo. He co-edited Educating Humanity: Bildung in Postmodernity (Blackwell; 2003). He is co-editor of Nordic fournal of Pedagogy and Critique (Nordisk Tidsskrift for Pedagogikk og Kritikk).

\section{References}

Dewey, J. (1916a). Democracy and education. New York, NY: The Free Press. Dewey, J. (1916b). Essays in experimental logic. New York, NY: Dover.

Dewey, J. (1929). Individualism old and new. New York, NY: Capricorn Books.

Dewey, J. (1939). Logic: The theory of inquiry. London: Allen and Unwin.

Dewey, J. (1927). The public and its problems. Chicago, IL: Swallow Press.

Dewey, J. (1958). Experience and nature. New York, NY: Dover.

Dewey, J. (1963a). Philosophy and civilization. New York, NY: Capricorn Books.

Dewey, J. (1963b). Liberalism and social action. New York, NY: Capricorn Books.

Gadamer, H.-G. (1965). Wahrheit und Methode [Truth and Method]. Tübingen: J.C.B. Mohr.

Hegel, G. W. F. (1977). Phenomenology of spirit. Oxford: Clarendon Press.

Heidegger, M. (1996). Being and time. Albany, NY: State University of New York Press.

Kestenbaum, V. (1977). The phenomenological sense of fohn Dewey: habit and meaning. Atlantic Highlands, NJ: Humanities Press.

Kestenbaum, V. (2002). The grace and the severity of the ideal. Fohn Dewey and the Transcendent. Chicago, IL: The University of Chicago Press.

Løvlie, L. (2007). The pedagogy of place. Nordisk Pedagogik, 27(1), 32-37.

Løvlie, L. (2013a). Verktøyskolen [The tool-kit school]. Norsk Pedagogisk Tidsskrift, 3, 185-199; and Unge Pcedagoger, 3, 71-83. 
Løvlie, L. (2013b). Danning til demokrati [Education for democracy]. In I. Straume (Ed.). Danningens filosofihistorie [The Philosophy of History of Education] (pp. 252-264). Oslo: Gyldendal.

Polanyi, M. (1966). The tacit dimension. London: Routledge.

Putnam, R. (2015). Our kids: The American dream in crisis. New York, NY: Simon \& Schuster.

Ryan, A. (1995). John Dewey, and the high tide of American Liberalism. New York, NY: W.W. Norton.

Taylor, C. (1989). Sources of the self. Cambridge, MA: Harvard University Press. 